\title{
MALIGNANT CELLS IN CEREBROSPINAL FLUID
}

\section{BY}

\author{
ARTHUR I. SPRIGGS \\ From the Division of Laboratories, United Oxford Hospitals
}

(RECEIVED FOR PUBLICATION OCTOBER 5, 1953)

Ever since the beginning of the present century, the identification of the cells in cerebrospinal fluid (C.S.F.) has been recognized as an important diagnostic procedure. Unfortunately, it has always been found a difficult matter to make stained films of these cells, and in fact the preparation of Romanowsky-stained, air-dried films comparable with those of blood has been considered almost impossible (Reichmann, 1911). In spite of the introduction of several alternative techniques, none has found a permanent place in laboratory practice, and the preparation of a film is usually omitted.

Presumably as a result of this difficulty, the number of reported cases in which tumour cells have been detected in C.S.F. is small. The fact that they can be found at all does not seem to be generally known. The purpose of this paper is to record seven cases of which six were subsequently proved to have meningeal spread of a malignant growth. (No post-mortem examination was permitted on the seventh.) These cases illustrate the importance of making stained films in cases of cerebrospinal pleocytosis, and a method for preparing such films is described.

\section{The Previous Literature}

Tables I and II list the 66 more or less acceptable cases which I have been able to find in the literature. In many of them the descriptions are inadequate, but no case has been excluded on this account alone.

Few of the reported cases are adequately illustrated, and it is difficult to draw from them a reliable picture of the types of cell to be expected from different tumours. One striking feature of the two tables is the high proportion of cases in which the meningeal infiltration was secondary to a carcinoma outside the central nervous system. A probable explanation of this is that metastatic carcinoma cells are relatively large, and are therefore likely to be recognized in the countingchamber. The smaller cells of, say, a medulloblastoma are likely to be passed over as lymphocytes or as "mononuclear cells."
Cases Excluded from the Tables. - The cases of Mohr (1912), Emanuel (1927), and Thurel, Poujo N and Contamin (1949) have been excluded because of unconvincing cytological data and the absencty of any evidence of meningeal spread of the growths. The first 11 of Forster's (1930) 12 cases are excluded for the same reasons ; the illustrations and descriptions are not in accord with my owe experience of tumour cells nor with that of other authors, and in several cases the tumours were benign.

TABLE I

PRIMARY INTRACRANIAL AND INTRASPINAL TUMOURS

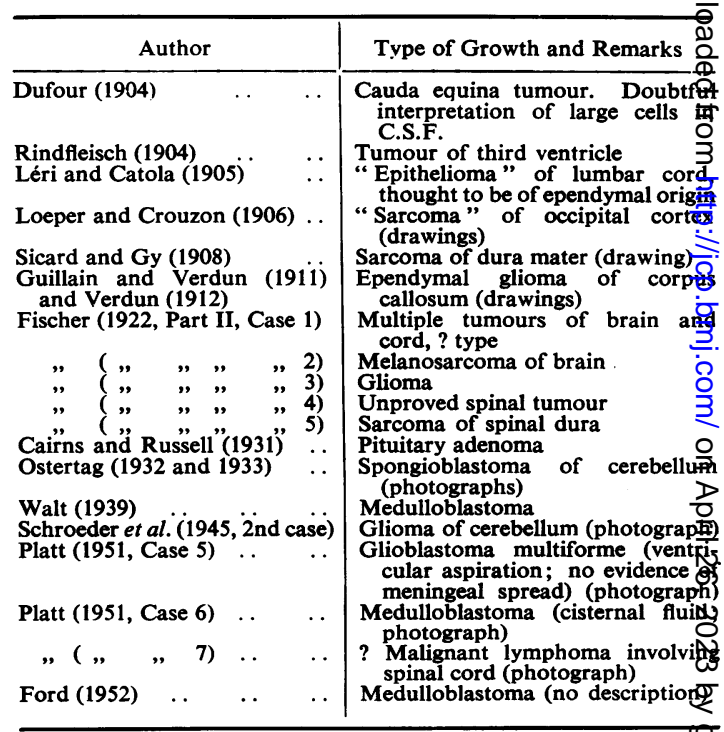

The last two of Larson, Robson, and Reberge (1953) five cases are excluded because of the absence of any evidence of meningeal spread and the paucity of the data. Cases 2 and 3 are ales not very convincing, but have been included; thefe is no mention of the state of the meninges post mortem.

Viklicky (1952, Case 2) has described a case off medulloblastoma with abnormal cells in the C.S.P. 
TABLE II

SECONDARY TUMOURS OF THE CENTRAL NERVOUS SYSTEM

\begin{tabular}{|c|c|c|}
\hline $\begin{array}{l}\text { Site of } \\
\text { Primary } \\
\text { Growth }\end{array}$ & Author & $\begin{array}{c}\text { Type of } \\
\text { Growth and Remarks }\end{array}$ \\
\hline Stomach & 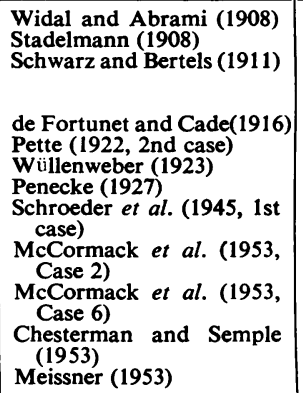 & 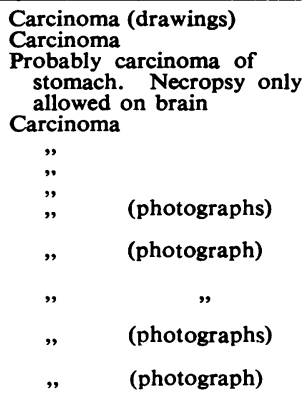 \\
\hline Lung .. & 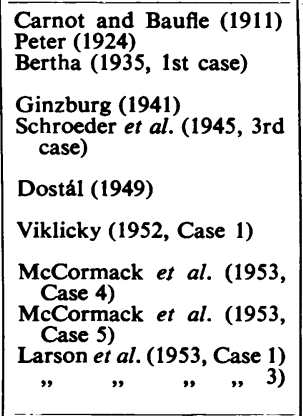 & $\begin{array}{l}\text { "Fuso-cellular sarcoma" } \\
\text { Carcinoma (photographs) } \\
\text { Pleomorphic carcinoma } \\
\text { (photograph) } \\
\text { Adenocarcinoma (drawings) } \\
\text { Carcinoma. Fluid obtained } \\
\text { by ventricular puncture } \\
\text { (photograph) } \\
\text { Anaplastic carcinoma } \\
\text { (photograph) } \\
\text { Adenocarcinoma } \\
\text { (photographs) } \\
\text { Adenocarcinoma } \\
\text { (photograph) } \\
\text { Adenocarcinoma } \\
\text { (photograph) } \\
\text { Carcinoma } \\
\text { Oat-cell carcinoma (photo- } \\
\text { graph) }\end{array}$ \\
\hline Breast & $\begin{array}{l}\text { Humbert and Alexieff(1913) } \\
\text { Lemierre and Boltanski } \\
\text { (1929) } \\
\text { Piaggio Blanco and Paseyro } \\
\text { (1945) } \\
\text { Pinto (1946. Case 1) } \\
\text { Nayrac et al. (1950) } \\
\text { McCormack et al. (1953, } \\
\text { Case 7) }\end{array}$ & $\begin{array}{cc}\begin{array}{c}\text { Carcinoma (drawing) } \\
\text { (drawings) }\end{array} & \begin{array}{c}\text { (photographs) } \\
,\end{array} \\
" & \text { " } \\
" & \text { (photograph) }\end{array}$ \\
\hline$\overline{\text { Kidney }}$ & $\begin{array}{l}\text { Fischer (1922, Part I, Case 5) } \\
\text { Fischer(1922 Part II,Case 4) } \\
\text { Bertha (1935, 2nd case) }\end{array}$ & $\begin{array}{l}\text { Hypernephroma } \\
\text { Adenocarcinoma(photograph) }\end{array}$ \\
\hline Pancreas & $\begin{array}{l}\text { McCormack et al. (1953, } \\
\text { Case 1) } \\
\text { McCormack et al. (1953, } \\
\text { Case 3) } \\
\text { Larson et al. (1953, Case 2) }\end{array}$ & $\begin{array}{l}\text { Carcinoma (photograph) } \\
\text { " } \\
\begin{array}{l}\text { Adenocarcinoma } \\
\text { (photograph) }\end{array}\end{array}$ \\
\hline Eye $\quad \cdots$ & Panton (1922) & Round-celled sarcoma \\
\hline$\overline{\text { Skin } \ldots}$ & $\begin{array}{l}\text { Boyd (1925) } \\
\text { McCormack et al. (1953, } \\
\text { Case 9) }\end{array}$ & $\begin{array}{c}\text { Melanoma } \\
\text { (photograph) }\end{array}$ \\
\hline$\overline{\text { Omentum }}$ & Facchini (1908) & " Endothelioma" \\
\hline Thymus & $\begin{array}{l}\text { Danisch and Nedelmann } \\
\text { (1928) }\end{array}$ & Malignant thymoma \\
\hline Thyroid & $\begin{array}{l}\text { Fischer (1922, Part I, Case } \\
\text { 1) }\end{array}$ & $\begin{array}{l}\text { Carcinoma, unproved } \\
\text { (drawings) }\end{array}$ \\
\hline $\begin{array}{l}\text { Primary } \\
\text { growth } \\
\text { unknown }\end{array}$ & $\begin{array}{l}\text { Meyer (1911 and 1922) } \\
\text { Pette (1922, 1st case) } \\
\text { Fischer (1922, Part I, Case } \\
\text { 2) } \\
\text { Forster (1930, 12th case) } \\
\text { Pinto (1946, Case 2) } \\
\text { McCormack et al. (1953, } \\
\text { Case 8) }\end{array}$ & $\begin{array}{l}\text { ? Adenocarcinoma of uterus } \\
\text { Adenocarcinoma, ? from } \\
\text { parotid tumour } \\
\text { Unproved; probably car- } \\
\text { cinoma of bowel } \\
\text { Anaplastic carcinoma } \\
\text { (photograph) } \\
\text { No histology (photographs) } \\
\text { Carcinoma (photograph) }\end{array}$ \\
\hline
\end{tabular}

and post-mortem proof of meningeal dissemination. Although the photographs are suggestive of tumour cells Viklicky does not accept them as such, and this case is therefore not included.

In Kono's (1924) case of choroid plexus tumour, malignant cells were only found in C.S.F. removed by lumbar puncture after death. He published no illustrations.

Fischer's (1922) nine cases have all been admitted, but the evidence in several of them is onlv slender.

\section{Material and Methods}

In the present series of seven cases, in which tumour cells were found in the C.S.F., all specimens of fluid were examined routinely in the Clinical Pathology Laboratory, Radcliffe Infirmary. During the period when they were seen, films were only made if unusual cells were seen in the counting-chamber, or if the examination for malignant cells was requested. It is likely that other cases were missed, owing to our failure to make stained films in all cases of pleocytosis.

All the cases in this series have been studied by means of air-dried films stained by Romanowsky stains. Although such films are not always easy to make, their interpretation is relatively straightforward to anybody accustomed to Romanowsky films of blood and marrow. The Papanicolaou method as applied to C.S.F. has not been found very satisfactory, and wet-chamber methods, such as that recently advocated by McCormack, Hazard, Gardner, and Klotz (1953), have the serious drawback of impermanence.

The method used is as follows:

As much C.S.F. as can be spared for the examination is centrifuged in a conical tube until the cells are deposited ; the supernatant fluid is poured off and can be used for other estimations. After pouring off the supernatant the tube is inverted so that no C.S.F. can run back on to the cells. The cellular deposit is then removed with a platinum loop. Usually a pinhead-sized portion can be made to adhere to the tip of the loop, and this is deftly spread out on a clean slide. If the cells are so scanty that there is no deposit removable in this way, this method cannot be used. The smear seldom covers more than 1 sq. $\mathrm{cm}$. Essential points are: (1) That the smear should dry instantaneously; if it takes a minute to dry, owing to excess of fluid, it may as well be discarded. (2) That no part of the smear should be scratched with the loop after it is dry.

The air-dried films are then fixed in methyl alcohol for three minutes and stained with Leishman's stain or with May-Grünwald-Giemsa in exactly the same way as blood or marrow films. May-Grünwald and Giemsa as described on page 402 of Dyke's Recent 
Advances in Clinical Pathology (2nd ed., Churchill, 1951) has been used in this investigation. Where red cells are numerous the method of choice is to centrifuge, remove the supernatant fluid, add a little fresh cell-free compatible serum (less than a drop), and make films exactly as for blood. The films from Case 7 in this series were made by Dr. J. B. Howie by this method. Films made by spreading without serum replacement are apt to be slow-drying and this impairs the subsequent staining.

In cases where sufficient cellular deposit can be obtained these methods give excellent results. A satisfactory way of making stained films from samples with very low cell counts remains to be devised. Some success has been obtained using a fine squirrel-hair paint-brush to transfer the deposit to the slide.

\section{Case Reports}

Case 1 (121640). - A woman aged 55 was admitted to hospital on March 20,1951, with a complaint of attacks of "beating" in the head for three months. The attacks had been increasing in severity, with giddiness and a sensation of pressure behind the eyes. When first admitted she had no neurological signs except for weakness of the right leg. The C.S.F. pressure was $160 \mathrm{~mm}$. $\mathrm{Hg}$, the protein $45 \mathrm{mg} . \%$, and the cells $19 \mathrm{c} . \mathrm{mm}$. with 12 lymphocytes and 7 polymorphs. A diagnosis of migraine was made. She was admitted again on April 11, 1951, with partial blindness and retention of urine. At this time there was gross diminution in the visual fields, loss of reaction of the left pupil, bilateral external rectus palsy, slight left facial weakness and a blood pressure of 155/120 $\mathrm{mm}$. Hg. The margins of the optic disc were blurred. Lumbar puncture produced clear fluid at a pressure of $100 \mathrm{~mm}$. $\mathrm{Hg}$, protein $80 \mathrm{mg}$. $\%$, cells $35 /$ c.mm. (33 lymphocytes, 2 polymorphs).

Rectal examination revealed a firm rounded mass in the pouch of Douglas, and a provisional diagnosis was made of ovarian carcinoma with intracranial metastases.

Lumbar puncture performed on April 17 produced clear fluid with a very light deposit of cells after centrifuging. These were mostly red cells, with lymphocytes, macrophages and some atypical cells reported as highly suggestive of malignancy.

Atypical Cells.-These cells were large (up to $24 \mu$ diameter), with large round nuclei (12-16 $\mu$ diameter), in some cases showing an ill-defined nucleolus, and moderately profuse foamy or cloudy cytoplasm. They did not adhere in clumps (Fig. 1). No mitotic figures were seen.

A necropsy performed on May 7 (P.M. 253/51) showed a primary adenocarcinoma of the rectosigmoid junction, with multiple secondaries. There was diffuse metastatic carcinomatosis of the meninges over the brain and spinal cord, histologically mostly undifferentiated in type but in places showing an adenocarcinomatous pattern.

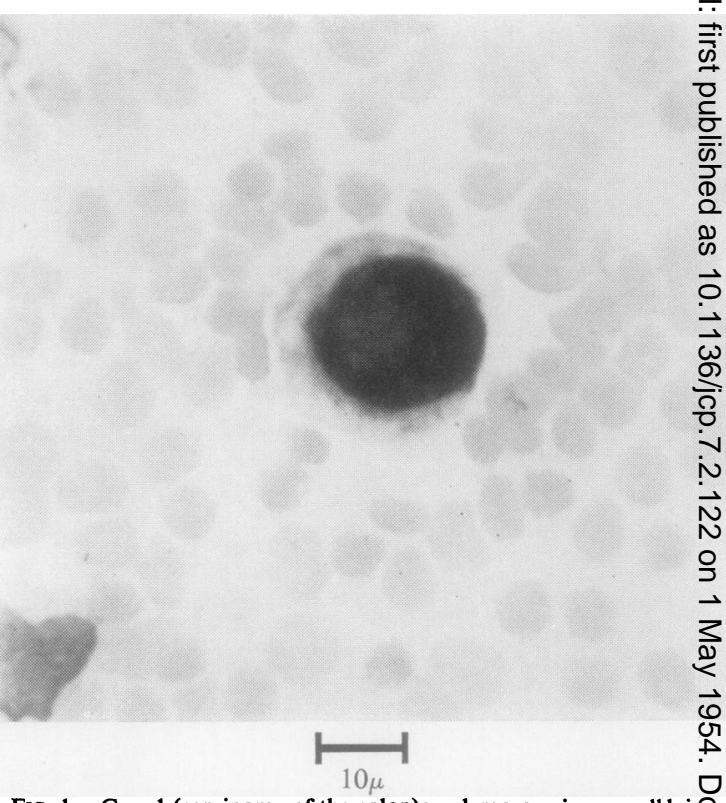

Fig. 1.-Case 1 (carcinoma of the colon): a large carcinoma cell lyin among red cells. It is easily identifiable by the size of its nuclest and the high nucleo-cytoplasmic ratio.

Case 2 (141793). - A woman aged 58 was admitteä on May 22, 1951, with seven weeks' history of mig thoracic girdle pains, and one week's history of weaks ness of the legs and difficulty in passing urine. Sho was found to have a sensory level at $\mathrm{T} \mathbf{4}$ and complete flaccid paralysis below this level. There was n⿳亠口冋阝 evidence of a primary growth outside the spine, and radiographs showed a paravertebral shadow in the mid-thoracic region. Lumbar puncture produce clear fluid with a protein content of $600 \mathrm{mg} . \%$ ang no cells. Films of centrifuged deposit were not made Myelography revealed a spinal tumour, and lamire ectomy was performed on May 24. A biopsy waš taken of an extrathecal tumour, and the sections showed plasma cell myeloma. She died on May 26

Cerebrospinal fluid obtained at the time of lamir? ectomy was centrifuged and films were examined.

Atypical Cells.-The films showed numerous large abnormal cells, closely resembling a type of "myeloma cell" seen in the bone marrow (Fig. 200 In most cases they lay separately from one anothes but sometimes in small aggregates. The whole cef in mononuclear examples measured 14-22 $\mu$ acros? but multinucleate cells sometimes reached $60 \mu$ i diameter. The nucleus usually had a diameter of 10 to $14 \mu$, but was sometimes as large as $22 \mu$ across; it lay eccentrically in most cases, and had an even but rather coarse chromatin structur\& There were one or several irregular large nucleo of sometimes measuring even up to $8 \mu$ across. The cytoplasm was stained deep blue, except for a juxte nuclear area of pallor, and was of ground-glass tex ture. There were occasionally a few punched-ot 


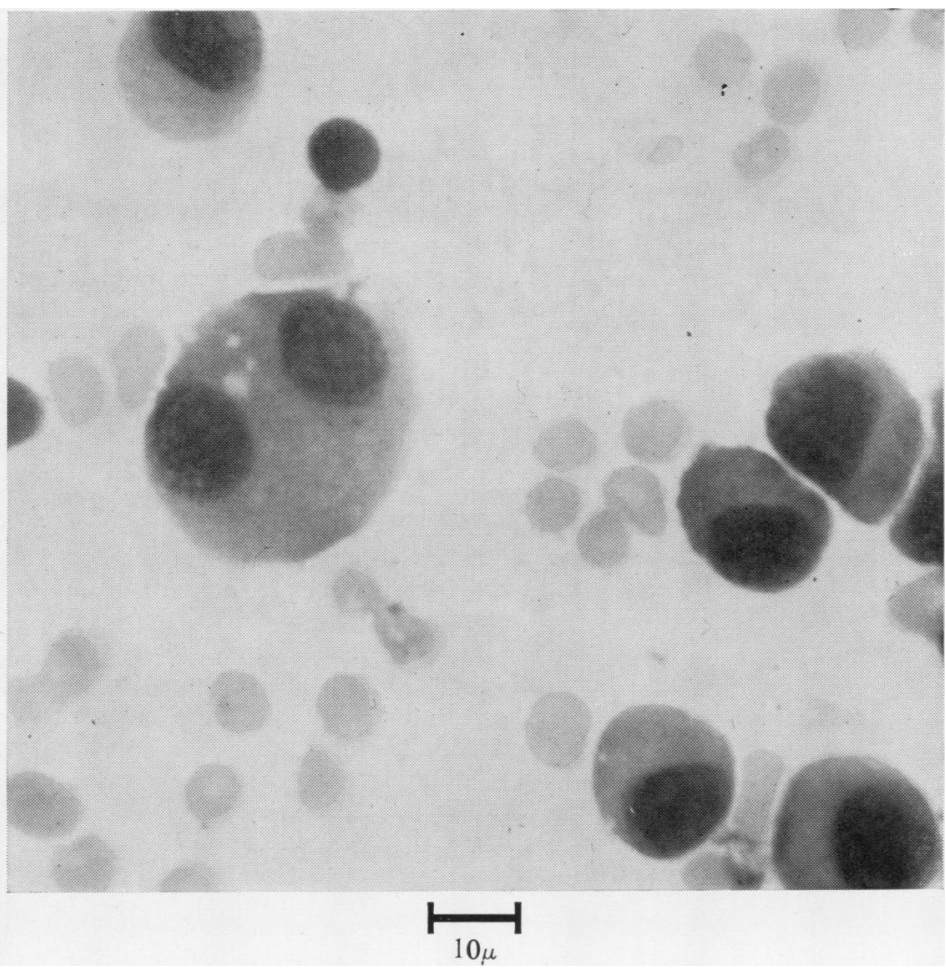

FIG. 2.-Case 2 (plasmacytoma) : characteristic myeloma cells with red cells and a few

with a fine chromatin structure, and with 1 to 3 nucleoli each measuring about $3 \mu$ across. The cytoplasm was in most cases rather scanty, moderately basophilic and almost clear. In some cases there were a few vacuoles. These cells occurred in clumps of dozens or even hundreds together (Fig. 3). No mitotic figures were observed.

Similar cells were seen in subsequent specimens of C.S.F. up till the time of transfer to the Royal Berks Hospital, Reading, on August 13. $X$-ray treatment was given for a supposed cerebral tumour. The boy died on April 27, 1952, and a necropsy (Dr. J. Mills) revealed bilateral soft paravertebral tumours extending downwards from the tenth thoracic vertebra and infiltrating the vertebral bodies. The brain and spinal cord were sent here for examination (S.H. 3218/52). The arachnoid cysts did not appear to be neoplastic, but there was massive infiltration of the spinal subarachnoid space with tissue identical with that of the paravertebral masses. Histologically the growth was a poorly differentiated connective tissue tumour, probably of a reticulosarcomatous nature.

vacuoles. Most cells were mononuclear, but cells with 2 to 4 nuclei were present and a few mitotic figures were seen.

Associated cells were erythrocytes and a few lymphocytes.

At necropsy on May 28 (P.M. 294/51) an extradural tumour was found arising in the ninth thoracic vertebra and extending extradurally from $T 1$ down to $\mathrm{T} 10$. Histologically this was a plasma-cell myeloma. The meninges showed only slight macroscopical granularity over the spinal cord, and microscopically scattered isolated myeloma cells were present in the subarachnoid space.

Case 3 (142365). - A boy aged 14 had about three months' history of pain in the neck and failure of vision in the right eye, with headaches and some vomiting. Radiological studies showed a defect in the anterior fossa, which was explored on June 7, 1951. A diffuse arachnoid cyst was found, the nature of which was not determined. He returned a month later with further failure of vision, and lumbar puncture on July 31 produced turbid yellow fluid under less than atmospheric pressure, with a protein content of $580 \mathrm{mg} . \%$. There were 16,000 red cells and 34 white cells per c.mm.

Atypical Cells.-Almost all the white cells were of the same type. They measured 10-18 $\mu$ across; the nuclei were round or irregular, almost filling the cell,

Case 4 (159933). - A girl aged 4 was admitted to another hospital on May 12, 1952, with headache, vomiting, and left-sided weakness of four weeks' duration. Left-sided weakness was confirmed, and a lumbar puncture produced fluid under $90 \mathrm{~mm} . \mathrm{Hg}$ pressure, with a protein of $30 \mathrm{mg} . \%$ and 11 cells per c.mm. She was regarded as a case of hemichorea. She was admitted again with headache and vomiting on June 19 and the C.S.F. was now under a pressure of $270 \mathrm{~mm}$. $\mathrm{Hg}$, bloodstained, with a protein of 180 mg.\%, chlorides $685 \mathrm{mg} . \%$, no sugar, and 55 white cells per c.mm., reported as lymphocytes. No acidfast bacilli were found.

On transfer here on June 21 she was found to have left-sided weakness and incoordination so that she was unable to walk. Lumbar puncture on June 24 produced turbid yellow fluid under $300 \mathrm{~mm}$. $\mathrm{Hg}$ pressure. The protein was $660 \mathrm{mg} . \%$, chlorides 660 mg. $\%$, sugar absent. There were 2,000 red cells and 500 white cells per c.mm.; almost all the latter were reported as tumour cells. Ventriculography the same afternoon showed a large tumour below the right lateral ventricle; smears of material aspirated from the tumour were reported by Dr. D. Bosanquet as follows :

"The smear shows much necrotic debris, scattered through which are tumour cells lying singly or in small clumps. These cells have little cytoplasm and 


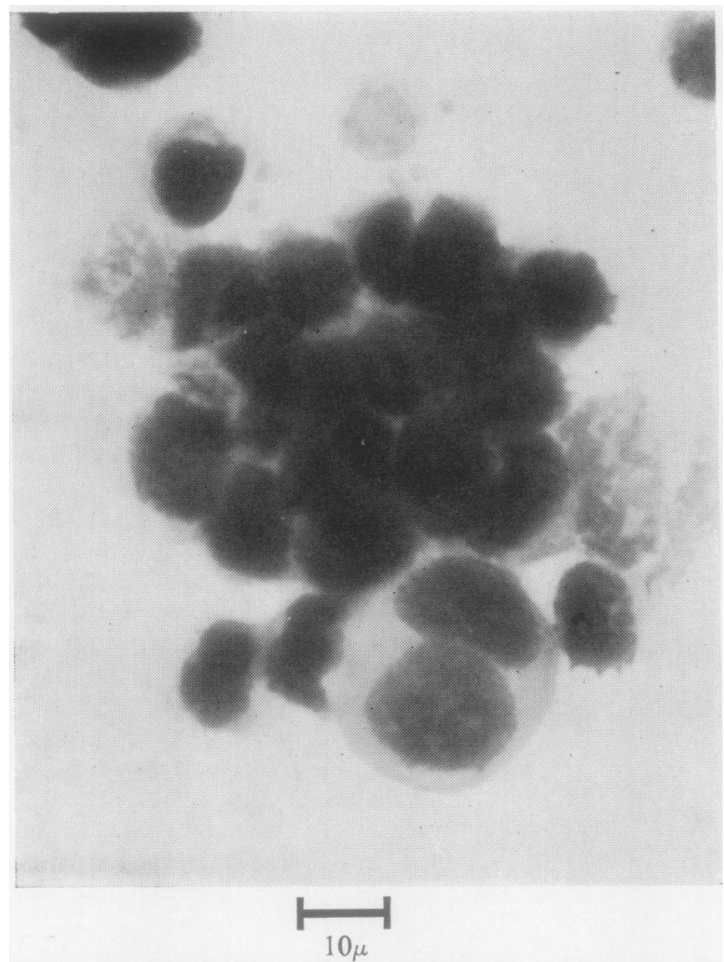

FIG. 3.-Case 3 (reticulosarcoma): collections of tumour cells with very scanty cytoplasm. A single large binucleate cell has profuse cytoplasm and prominent enlarged nucleoli.

round vesicular nuclei with a well-marked nucleolus and nuclear membrane. Mitoses are present in moderate numbers. The appearance is unusual and the cells do not look like those from a medulloblastoma or any of the commoner gliomas; it is possible that the primary tumour is outside the central nervous system, but no diagnosis can be made other than that it is certainly a malignant tumour."

A further two specimens of C.S.F. both showed the same type of cells as had been seen before. The child died on June 28, and permission for necropsy was refused.

Atypical Cells.-The cells either lay separately from one another or aggregated into clumps of up to 30 together (Fig. 4). Each cell measured from 12 to $22 \mu$ across. The nucleus was polygonal or irregular in shape, 10 to $20 \mu$ in diameter, with a fine chromatin structure and one or more well-marked nucleoli staining pale blue and sometimes measuring as much as $4 \mu$ across. The cytoplasm was scanty, staining deep blue, and sometimes showing a large vacuole near the cell centre and a few small punched-out vacuoles probably due to fat. Mitoses were not observed.

Case 5 (162892). - A boy aged $2 \frac{1}{2}$ was admitted to another hospital on August 30, 1952, with two or three weeks' history of impaired appetite and a week's history of vomiting and drowsiness. He became un- conscious on the day of admission. Clinically he showed mengingitic signs, and lumbar puncture prow duced fluid under more than $300 \mathrm{~mm}$. $\mathrm{Hg}$ pressure.0 The protein was $89 \mathrm{mg} . \%$, chlorides $756 \mathrm{mg} . \%$, sugaro content normal. There were 114 cells per c.mm., six $\overline{\bar{c}}$ being polymorphs and 101 interpreted as lympho- $\bar{\Phi}$ cytes. No acid-fast bacilli were found. He was transferred to the Radcliffe Infirmary on August 31 . as a possible case of tuberculous meningitis, andC.S.F. obtained by lumbar puncture here contained $110 \mathrm{mg} . \%$ of protein, $660 \mathrm{mg} . \%$ of chlorides, normal $\vec{\omega}$ sugar, and 1,300 cells per c.mm. Many of these cellso occurred in clumps of 10 to 20 ; they were at firsto thought to be lymphocytes, but stained films showed them to be tumour cells.

A ventriculogram done the same day showed $a-$ deformity of the fourth ventricle, and on September 1 exploration and decompression were performed.o The condition was found to be a cerebral tumour. with meningeal spread; a biopsy showed a medulloblastoma.

A post-operative specimen of C.S.F., besides abundant red cells, contained 1,800 white cells per c.mm. $\overrightarrow{0}$ almost all tumour cells (Fig. 5).

Atypical Cells.-The cells referred to as tumour cells were not very large, measuring only 9 to $15 \mu$ across. The nucleus almost filled the cell. Its

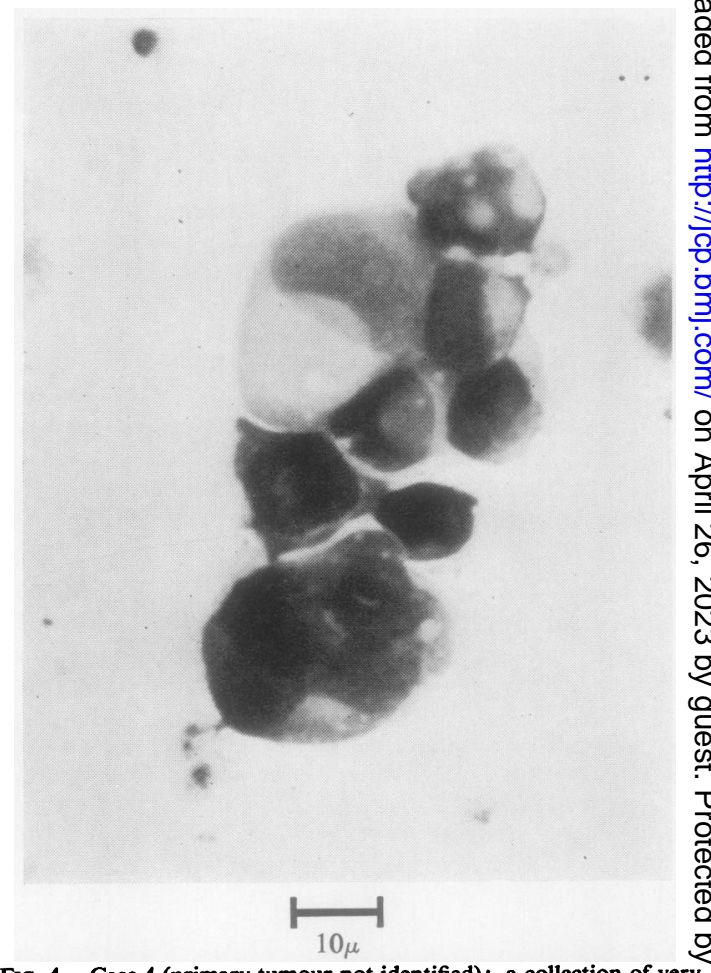

FIG. 4.-Case 4 (primary tumour not identified): a collection of very pleomorphic tumour cells. There is a strikingly high nucleo@ cytoplasmic ratio, and several cells appear to have secretoryo vacuoles. 


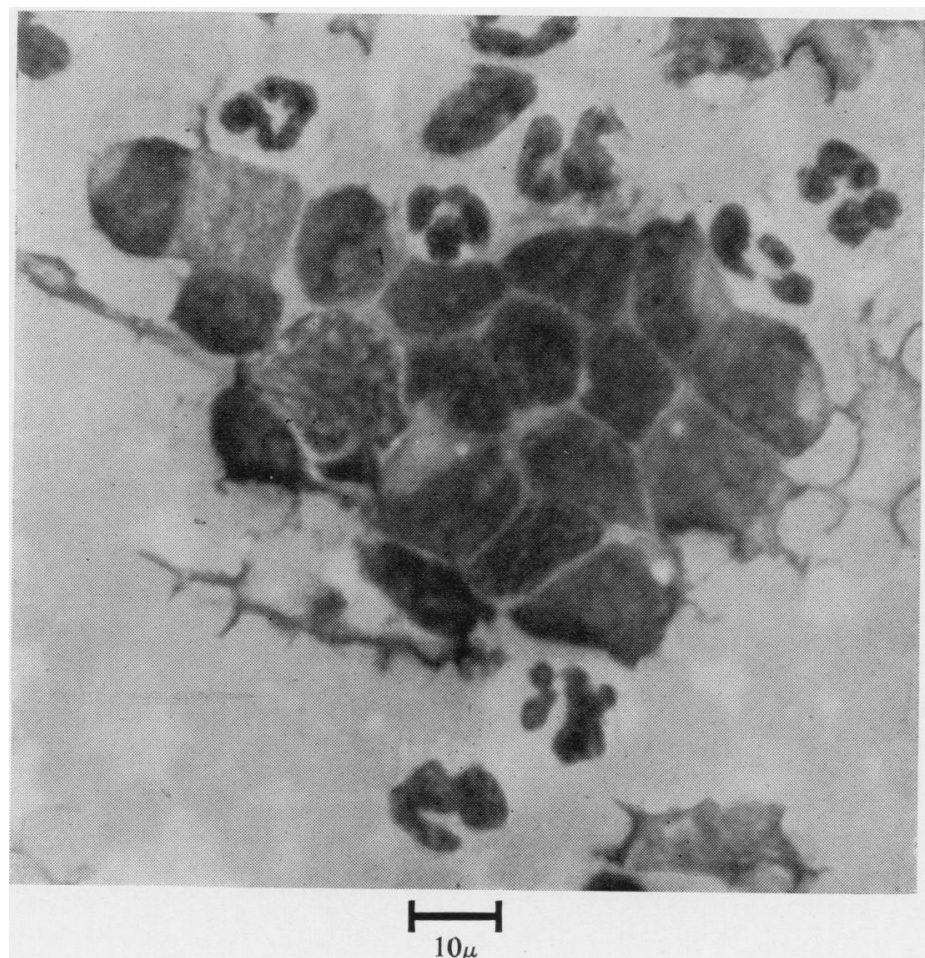

FIG. 5.-Case 5 (medulloblastoma): a clump of medulloblastoma cells among closely packed red cells and neutrophils. The tumour cells are larger than lymphocytes and have very scanty cytoplasm; their nuclear chromatin is fine and nucleoli are visible. They could easily be confused with monocytes or large lymphoid cells, but their occurrence in clumps and their fine chromatin pattern are distinguishing features.

clot was present after standing; there were 300 red cells and 15 white cells per c.mm., the latter consisting of seven neutrophils and eight lymphocytes. Another lumbar puncture on November 18 showed a similar finding.

A ventriculogram showed no spaceoccupying lesion.

On November 25 at lumbar puncture a lightly bloodstained yellow fluid was obtained containing over $1,000 \mathrm{mg}$. of protein per $100 \mathrm{ml}$. It clotted spontaneously. There were 2,500 red cells and 22 white cells per c.mm.; of the latter, 10 were neutrophils, 8 lymphocytes, and 4 " atypical" cells. For the first time, stained films were made and the atypical cells were reported as probably malignant. They were found again in subsequent specimens (Fig. 6).

Atypical Cells.-The cells were isolated from one another and measured 12-22 $\mu$ across. The nucleus was generally single, but in some cells 2 to 4 nuclei were present. When single, the nucleus usually lay to one side of the cell, and was round or irregular, measuring anything from 10 to $20 \mu$ in diameter. The chromatin pattern was fine, and there were up to five ill-defined nucleoli of normal size. The cytoplasm was scanty, staining greyish blue, with a

chromatin structure was fine, and each nucleus contained one or more relatively large nucleoli, sometimes as much as $4 \mu$ in diameter. No mitoses were seen. The cytoplasm was scanty and moderately basophilic. Both nucleus and cytoplasm often showed a few very small clear vacuoles.

These cells occurred in clumps, often of dozens together, and owing to their scanty cytoplasm the nuclei were closely applied to one another, producing a mosaic-like effect.

The child died, and a necropsy (P.M. 452/52) showed massive subarachnoid spread of a medulloblastoma arising in the cerebellum.

Case 6 (166531).-A woman aged 52 was admitted on November 14, 1952, with a history of lumbar pain for several days in August, thought to be due to a prolapsed disc, and subsequent abdominal pain and vomiting. A few days before admission she became disorientated and suffered from frontal headache. The principal findings on examination were slight left facial weakness, right foot drop, and a little pain on right straight-leg-raising. She was mentally confused and uncooperative.

Lumbar puncture on November 15 produced yellow "syrupy" fluid under $180 \mathrm{~mm}$. $\mathrm{Hg}$ pressure. The protein content was above $1,000 \mathrm{mg}$. per $100 \mathrm{ml}$., and ground-glass appearance. Sometimes there was a vacuole next to the nucleus, but this was not stained by the periodic-acid-Schiff method following salivary digestion, and was therefore probably not mucus-secreting. None of these cells were seen in mitosis.

The patient became comatose and died on December 2.

At necropsy (P.M. 606/52) the whole cord and cauda equina and the subarachnoid cisterns of the brain were found to be enveloped in a gelatinous exudate, and there was a tumour in the region of the pineal gland and slight enlargement of the left thalamus. No primary tumour was found outside the central nervous system.

Histologically the tumour proved to be a glioma spreading as a diffuse astrocytoma through the pulvinar on one side and showing anaplastic change to become a glioblastoma multiforme near the posterior surface, whence it involved the leptomeninges.

Case 7 (171953). - A woman aged 57 was first admitted in March, 1953, with a year's history of lassitude and vomiting, and about six weeks' history of headaches, failure of vision, and loss of weight. She had also had several fits. She was found to be hypertensive and to have tenderness over the sub- 


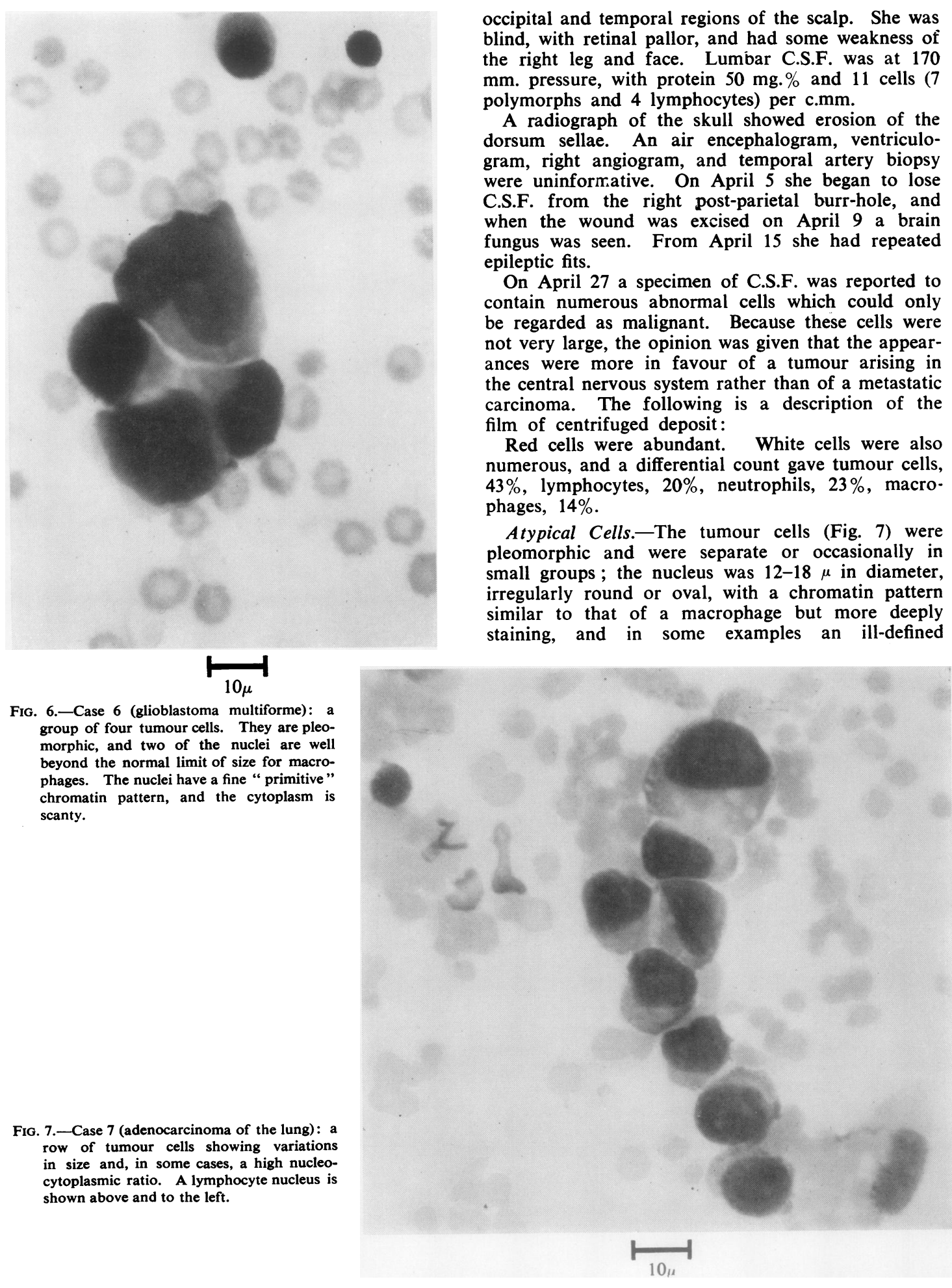


nucleolus was visible. The nucleo-cytoplasmic ratio was often high, but in some cells the cytoplasm was fairly profuse; the total diameter of the cell was from 15 to $24 \mu$, usually 16 to $18 \mu$. The cytoplasm was moderately basophilic, cloudy, sometimes containing fat vacuoles. Here and there a cell showed an ill-defined vacuole at the cell centre which appeared to deform the nucleus. The periodic-acidSchiff stain on ptyalin-digested slides did not demonstrate any mucus in these vacuoles. A few cells in mitosis were present. The "macrophages" were large and in some instances perhaps represented degenerating tumour cells.

No other evidence of a neoplastic process was obtained during life.

The patient was transferred to Stoke Mandeville Hospital on May 7 and died two months later. At necropsy (Dr. H. J. Harris) she was found to have a bronchial carcinoma. The meninges showed only slight macroscopic thickening, but sections showed very extensive infiltration of the subarachnoid space with adenocarcinoma.

\section{Discussion}

Malignant cells cannot be distinguished by any single morphological feature. The diagnosis of malignancy from isolated cells can be either easy or very difficult according to the type of growth and the cellular environment. In the case of C.S.F. there is not a very large variety of cell types from which tumour cells have to be distinguished, and in well-stained films the diagnosis is sometimes obvious. The following are the principal criteria on which the diagnosis is based: (1) The cells are foreign to their environment: they differ from any type of cell occurring in the C.S.F. in other conditions. (2) The cells morphologically resemble those seen in particular varieties of tumour: for example, in Case 2 they were recognizably like "myeloma cells" of the bone marrow. (3) The cells may show some of the features characteristic of tumour cells in general: of these the most noteworthy are large size, especially of the nucleus; high nucleocytoplasmic ratio; reduplication of nuclei; enlargement of nucleolus; great variation in size and shape of otherwise similar cells; and frequent mitoses.

None of the above features is present in every case, and none by itself is of particular significance. The cases described here and the descriptions in the literature are not numerous enough to allow many generalizations to be made about even the commonest types of malignant cells seen in C.S.F. It seems that metastatic carcinoma cells are usually exceptionally large, with absolutely and relatively large nuclei, but adenocarcinoma cells show much less tendency to form morular or acinar structures than they do in pleural or peritoneal effusions. The small anaplastic cells of medulloblastoma are distinguished by a "primitive" chromatin pattern, high nucleo-cytoplasmic ratio, and occurrence in aggregates. Mitotic figures were seen in only Cases 2 and 7 , and are not to be expected in most types of tumour cell ; they also occur in non-malignant fluids, particularly among plasma cells, and their presence is therefore of little diagnostic help.

In all the seven cases of the series lumbar puncture had been previously performed, sometimes repeatedly, and yet malignant cells had not been discovered because they were not looked for. In Cases 1, 2, 4, and 5 the diagnosis was made by other means either before or at the time of discovery of malignant cells. In Cases 3,6 , and 7 the finding of malignant cells in the C.S.F. was the only firm evidence of a malignant tumour to be obtained before death. In Case 7 the diagnosis of neoplastic infiltration of the meninges was thought unlikely on clinical grounds even after the cytological findings had been reported. No evidence was forthcoming until necropsy was performed. Case 5 is particularly instructive in that the symptoms and signs mimicked those of tuberculous meningitis, and the initial finding of considerable numbers of "lymphocytes" supported this diagnosis. Subsequent examination of a stained film showed that the cells bore very little morphological resemblance to lymphocytes.

It must be emphasized that mistakes can only be avoided if the examiner is thoroughly familiar with the cells of non-malignant conditions studied by the same technique, and a certain degree of skill in the making of the films is also essential.

Once this experience has been acquired, the examination of stained films for tumour cells can be a valuable, simple, and rapid diagnostic procedure, and is to be recommended in all cases of cerebrospinal pleocytosis where the cause is not already known.

\section{Summary}

Seven cases are described in which tumour cells were recognized in the cerebrospinal fluid during life. In six cases there was post-mortem proof of meningeal dissemination of malignant growth, and in the seventh necropsy was refused.

Of the six complete cases, two had primary cerebral tumours (a glioblastoma multiforme and a medulloblastoma), two had adenocarcinomata, one had a reticulosarcoma, and one had a myeloma as the primary growth. 
Sixty-six other cases have been found in the literature.

A method for making Romanowsky-stained films of C.S.F. deposits is described, and the preparation of such films is recommended in cases of pleocytosis of doubtful cause.

I wish to thank Dr. A. H. T. Robb-Smith and Dr. P. D. Daniel for their advice and encouragement ; Dr. Dawn Bosanquet for most of the post-mortem examinations and histology, and for much valuable help ; Dr. J. Mills and Dr. H. J. Harris for the postmortem reports on Cases 3 and 7 respectively; Mr. Joe Pennybacker for permission to publish the case reports; and Mr. K. E. White, who in several cases first detected tumour cells in the counting chamber.

\section{REFERENCES}

Bertha, H. (1935). Mschr. Psychiat. Neurol., 91, 15.

Boyd, W. (1925). Amer. J. Path., 1, 583.

Cairns, H., and Russell, D. S. (1931). Brain, 54, 377

Carnot, P., and Baufle, P. (1911). Bull. Soc. méd. Hôp. Paris, 3 ser., 32, 535.

Chesterman, F. C., and Semple, R. (1953). Arch. Middx Hosp., n.s., $3,201$. Danisch, F., and Nedelmann, E. (1928). Virchows Arch. path. Anat.,
268, 492 .

Dostál, O. (1949). Lék. Listy, 4, 304.

Dufour, H. (1904). Rev. neurol., Paris, 12, 104.

Emanuel, -. (1927). Zbl. ges. Neurol. Psychiat., 45, 287.

Facchini, - . (1908). Policlinico, Sez. prat., 15, 977.

Fischer, O. (1922). Z. ges. Neurol. Psychiat., 76, 81

Ford, F. R. (1952). Diseases of the Nervous System in Infancy, Childhood and Adolescence, 3rd ed., p. 842. Blackwell Scientific Publications, Oxford.

Forster, E. (1930). Z. ges. Neurol. Psychiat., 126, 683.
Fortunet, D. de, and Cade, A. (1916). Progr méd., Paris, 43, 132. Ginzburg, I. A. (1941). Probl. Neurosurg., Moscow, 5, 87.

Guillain, G., and Verdun, M. (1911). Bull. Soc. méd. Hôp. Paris, 32, 521 .

Humbert, G., and Alexieff, W. (1913). Rev. Médecine, 33, 921.

Kono, N. (1924). Frankfurt. Z. Path., 30, 92.

Larson, C. P., Robson, J. T., and Reberger, C. C. (1953). J. Neurosurg., $10,337$.

Lemierre, A., and Boltanski, E. (1929). Bull. Soc. méd. Hôp. Paris. p. 567.

Léri, A., and Catola, G. (1905). Rev. neurol., Paris, 13, 768.

Loeper, M., and Crouzon, -. (1906). Clin. med. Hôtel-Dieu, Paris (Clin et lab.), 5, 316.

McCormack, L. J., Hazard, J. B., Gardner, W. J., and Klotz, J. G. (1953). Amer. J. clin. Path., 23, 470.

Meissner, G. F. (1953). Cancer, 6, 313.

Meyer, E. (1911). Disch. med. Wschr., 37, 1052.

(1922). Arch. Psychiat. Nervenkr., 66, 283.

Mohr, R. (1912). Dtsch. Z. Nervenheilk., 44, 417.

Nayrac, P., Sevin, - ., Niquet, -., and Taquet, - . (1950). Rev. neurol., Paris, 82, 38.

Ostertag, B. (1932). Klin. Wschr., 11, 862.

(1933). Nervenartzt, 6, 225.

Panton, P. N. (1922). Lancet, 2, 762.

Penecke, R. (1927). Med. Klin., 23, 1645.

Peter, C. (1924). Z. ges. Neurol. Psychiat., 89, 1.

Pette, H. (1922). Disch. Z. Nervenheilk., 74, 226.

Piaggio Blanco, R. A., and Paseyro, P. (1945). Arch. urug. Med.,

27, 145.

Pinto, J. A. (1946), Dia méd., 18, 744.

Reichmann, V. (1911). Dtsch. Z. Nervenheilk., 42, 1.

Rindfleisch, W. (1904). Ibid., 26, 135.

Schroeder, A. H., Ardao, H., Éstrella, J. C., Enciso, R., and Medoc, J. (1945). An. Fac. Med. Montevideo, 30, 19.

Schwarz, E, and Bertels, A. (1911), Dtsch. Z. Nervenheilk, 42, 85.

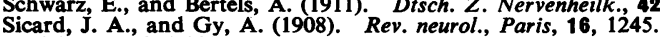

Stadelmann, E. (1908). Berl. klin. Wschr., 45, 2262.

Thurel, R., Poujol, J., and Contamin, F. (1949). Rev. neurol., Paris, 81,612 .

Verdun, M. (1912). Etude anatomo-clinique sur les complications méningées des tumeurs cérébrales. Thesis, Paris.

Viklicky, J. (1952). Lék. Listy, 7, 6.

Walt, F. (1939). Arch. Dis. Childh., 14, 84.
Widal, F., and Abrami, P. (1908). Bull. Soc. méd. Hôp. Paris, 3 ser., 25, 335 .

Wüllenweber, G. (1923). Münch. med. Wschr., 70, 1200. 